Abant Tıp Dergisi

Araştırma Makalesi / Cilt 9 Sayı 3 Yıl 2020
Abant Medical Journal

Research Article /Volume 9 Issue 3 Year 2020

\title{
Çocuklarda Migren Özelliklerinin Obezite ile İlişkisinin Araştırılması
}

Relationship Between Migraine Features and Obesity in Children

Hande GAZETECI TEKIN ${ }^{1}$ iD , Deniz ÖZALP KIZILAY²

${ }^{1}$ Bakırçay üniversitesi, Çiğli Eğitim ve Araştırma Hastanesi Çocuk Nörolojisi, İzmir - Türkiye

${ }^{2}$ Izmir Çiğli Bölge Eğitim Hastanesi, Çocuk Endokrin Kliniği, İzmir - Türkiye

öz

GiRiş ve AMAÇ: Migren ve obezite çocukluk çağında sık görülen iki hastalıktır. Çalışmalarda, obez çocuklarda migren sıklığının daha yüksek olduğu gösterilmiştir. Multifaktöriyel etyolojiye sahip olan bu iki hastalığın yollarının, hipotalamik disregülasyon ya da adipoz dokuya etkisi olan hormonal tetikleyicilerin etkisi ile kesiştiği düşünülmektedir. Biz bu çalışmamızda, obez olan ve olmayan çocuklarda migren özelliklerini ve PedMıDAS skorlarını karşılaştırmayı amaçladık.

YÖNTEM ve GEREÇLER: Baş ağrısı nedeniyle çocuk nöroloji polikliniğine başvurmuş ve IHD-3 beta versiyonuna göre migren tanısı almış hastalar, vücut kütle indekslerinin persentil değerlerine göre obez ve obez olmayan olarak iki gruba ayrıldı. Bu iki grubun demografik özellikleri ve son 3 ayda tuttukları baş ağrısı günlükleri ile değerlendirilen migren atak sıklığı, atak süresi, atak şiddeti ve PedMIDAS skorlarını içeren migren özellikleri istatistiksel yöntemler ile karşılaştırıldı.

BULGULAR: Çalışmaya 35 obez ve 35 obez olmayan toplam 70 migren tanısı olan hasta alındı. Yaş ortalaması 14,04 $\pm 2,4$

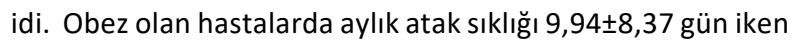
obez olmayan hastalarda 7,02 $\pm 5,28$ idi. PedMIDAS skorları da obez hastalarda $26,74 \pm 20,32$ iken obez olmayanlarda

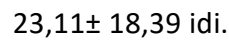

TARTIŞMA ve SONUÇ: Çalışmamızda obez olan ve olmayan, migren tanısı ile izlenen, benzer demografik özelliklere sahip hastalar arasında migren atak sıklığı, süresi, şiddeti ve PedMIDAS skorları arasında anlamlı bir fark bulunmamıştır.

Anahtar Kelimeler: Migren, obezite, çocuk, PedMIDAS

\section{Abstract}

INTRODUCTION: Migraine and obesity are two very common diseases in childhood. Studies show that the frequency of migraineis higher in obese children. It is thought that the pathways of two diseases with this multifactorial etiology intersect with the effect of hormonal triggers that have an effect on hypothalamic dysregulation or adipose tissue. In this study, we aimed to compare migraine features and PedMIDAS scores between obese and non-obese patients.

METHODS: Patients who applied to the pediatric neurology outpatient clinic due to headache and were diagnosed with migraine according to the IHD-3 beta version were divided into obese and non-obese groups according to percentile values of their body mass index. The demographic characteristics of these two groups and migraine characteristics including the frequency of migraine attacks, duration of attacks, attack severity and PedMIDAS scores evaluated by the headache diaries they kept in the last 3 months were compared with statistical methods.

RESULTS: A total of 70 children consisting of 35 obese and 35 non-obese patients were included in the study. The mean age is $14.04 \pm 2.4$. Migraine frequency was $9.94 \pm 8.37$ days/months in obese patients, it was $7.02 \pm 5.28$ days/months in non-obese patients. PedMIDAS scores were $26.74 \pm 20.32$ in obese patients and $23.11 \pm 18.39$ in nonobese patients.

DISCUSSION and CONCLUSION: In our study, no significant difference was found between migraine frequency, duration, severity, and PedMIDAS scores among patients with the demographic characteristics that were monitored with the diagnosis of obese and non-obese migraine.

\section{GíRiş}

Obezite ve migren, genetik ve çevresel faktörlere bağıı oluşan, son zamanlarda birbiri ile ilişkilendirilen ve çocukluk çağında sık görülen iki hastalıktır. Ancak, obezitenin primer baş ağrısı tipleri ile ilişkisi halen gösterilememiştir $(1,2)$.
Keywords: Migraine, obesity, child, PedMIDAS

Obezite ile migren ilişkisinde inflamatuar mediatörler, nörotransmitterler ve sitokinlere ek olarak hormonal tetikleyicilerin de etken olduğu düşünülmüş ve bu konuda çalışmalar yapılmıştır (3-6). Kalsitonin geni ilişkili peptid (CGRP), serebral ve dural damarlar üzerinde potent bir vazodilatatördür ve nörolojik inflamasyon ile 
trigeminovasküler ağrıya neden olmaktadır (3). Oreksin A ise CGRP salgılanmasını azaltan bir hipotalamik peptidtir ve düşük oreksin $A$ seviyeleri, trigeminal sinir aracilığıyla migren ataklarına neden olabilir. Obezlerde normal popülasyona göre gözlenen düşük oreksin $A$ değerlerinin migrene sebep olduğu düşünülmektedir $(4,7)$. Daha önce yapılan çalışmalarda, adiponektin seviyeleri migren şiddeti ile ilişkilendirilmiştir, yine leptin düşüklüğü obeziteye neden olurken diğer taraftan leptinin vasküler endotel hücre hasarı ile epizodik migrene neden olduğu savunulmuştur $(5,6,8)$.

Obezitenin, migren gelişmesinde risk faktörü olduğu ya da atak sıklığı ile ilişkili olduğu gösterilmiştir (9-12). Bigal ve ark.' larının yaptığı geniş çaplı çalışmada, 30.215 baş ağrılı hasta değerlendirilmiş; migren tanısı alan obezlerde, normal kilolu hastalara göre atak sıklığının 7.7 kat daha fazla olduğu bulunmuştur (12). Yine geniş çaplı başka bir çalışmada, vücut kitle indeksi (VKi) yüzdesinin migreni olan çocuklarda atak sıklığı ile ilişkili olduğu gösterilmiştir (13). Çocukluk çağında obez hastalar ile normal kilolu hastaların migren atak sıklığı daha önce yapılan çalışmalarda karşılaştırılmıştır ancak migrenin diğer bileşenleri olan atak ciddiyetinin, süresinin ve eşlik eden kusma, aura gibi semptom varlığının karşılaştırılığı çalışma sayısı çok azdır. Hayat kalitesini etkileyen ve iş gücü kaybına neden olan migren bileşenlerinin atak sayısından ziyade, atak süresine, ciddiyetine, eşlik eden semptomlara bağlı olduğunu düşünmekteyiz. Bu bileşenleri saptamaya yönelik geliştirilmiş PedMIDAS (Pediatric Migraine Disability Assessment Score) gibi skorlama sistemlerinin karşılaştırılmalı çalışmalarda kullanılması, migrenin günlük yaşama etkisini daha iyi yansıtacaktır (14). Günümüzde migrenin etkilerinin belirlenmesi, profilaksi kararının verilmesi, kronikleşme sürecinin takibi PedMIDAS skorlama sistemi ile yapılmaktadır. Biz bu skorları ve özellikleri iki grup arasında karşılaştırıp, günlük hayata etkilerini ortaya koymayı amaçladık.

\section{GEREÇ ve YÖNTEMLER}

Tek merkezli, kesitsel ve klinik temelli olan bu çalışma, Aralık 2019 ile Mart 2020 arasında migren tanısı ile çocuk nöroloji polikliniğe başvuran ve daha önce verilen baş ağrısı günlüklerini eksiksiz olarak tamamlamış, $35 \mathrm{obez}$ olan ve 35 obez olmayan çocuk hasta ile yapıldı. Hastalar hastaneye başvuru sırasına göre randomize olarak seçildi. Çalışmaya katılan hastalardan ve ebeveynlerden yazılı onam alındı. Çalışma protokolü için Tıbbi Etik Kurul onayı alındı ve çalışma Helsinki Deklarasyonu kapsamında yapıldı.

Çocuk nöroloji bölümüne baş ağrısı nedeniyle başvuran hastalar arasında IHD-3 beta versiyonuna göre migren tanısı alan tüm hastaların demografik özellikleri ve son 3 ayda tuttukları baş ağrısı günlükleri ile değerlendirilen migren özellikleri kaydedildi. Hastalar, herhangi başka bir seçime tabi tutulmadan, hastaneye başvuru sırasıyla çalışmaya dahil edildi. Bu hastaların antropometrik ölçümleri, sabah aç karnına ve ölçümü yapılan çocuğun ayakkabıları ve üst giysileri çıkarılmış haldeyken yapıldı. Hastaların boyları 0,1 cm ölçme hassasiyetine sahip Harpenden stadiometresi (Holtain Limited, Crymych, Dyfed, U.K) ile, vücut ağırlıkları (VA) 0,1 $\mathrm{kg}$ hassasiyetle ölçen SECA (isim olup, açılımı yoktur) (GMBH \& CO KG Hamburg, Germany) tartısı ile değerlendirildi. VKi; $\mathrm{VA}(\mathrm{kg})$ / Boy $(\mathrm{m}) 2$ formülü ile hesaplandı. VA standart deviasyon skoru (SDS), boy SDS ve VKi SDS değerleri Olcay Neyzi verileri kullanılarak hesaplandı. Türk çocukları için oluşturulmuş ölçeklere göre VKi persantili \%95 ve üstü olan olgular obez olarak kabul edildi (15). Pubertal evreleme, inspeksiyon ve palpasyon ile Marshall ve Tanner yöntemine göre yapıldı. Migren tanısı alan hastalar arasında obez ve obez olmayan hasta sayısı 35 hastayı bulduktan sonra örneklem tamamlandı.

Daha önce migren tanısı konulan ve son 3 ay boyunca baş ağrısı günlüğünü eksiksiz olarak tutan hastalar çalışmaya dahil edildi. Baş ağrısı 
günlüğünde; baş ağrısının olduğu günler, ağrı süresi, ağrı şiddeti (10 üzerinden), ağrı esnasında eşlik eden bulantı-kusma ve/veya fono-fotofobi varlığı, ağrının; ağrı kesici ilaç alımı, okula gidememe, okuldan eve dönmek zorunda kalma, evde ders çalışamama ya da sosyal bir etkinliğe katılamamaya neden olup olmadığı yer almaktaydı. Bu günlükler hastalar tarafından ebeveyn kontrolü ile tutulmuştur. Günlükler yardımıyla her hastanın PedMIDAS skorları hesaplandı (14) (Tablo 1).

Hastalardan bazılarına, tuttukları günlük, PedMIDAS skorları ve yaşam kalitelerindeki aksaklıklar göz önüne alınarak migren profilaksisi başlandı. Obez olan ve olmayan hastaların özellikleri istatistiksel yöntemler ile karşılaştırıldı.

\section{İstatistik}

İstatistiksel analizlerden ortalama, ortanca, sıklık, standart deviasyon (SD) gibi ölçümler Statistical Package for Social Sciences (SPSS) Software for Windows, version 23.0 programı ile yapılmış,

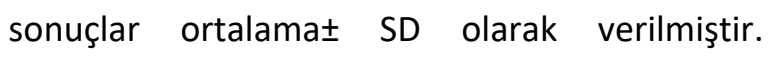
Verilerin homojen dağılımı Kolmogorov-Smirnov testi kullanılarak değerlendirildi. Grupların karşılaştırılmasında normal dağılanlarda Student $\mathrm{Gg}$ t testi, normal dağılmayanlarda Mann-Whitney U testi ve grup oranlarının karşılaştırılmasında Pearson ki-kare testi uygulandı. $p<0.05$ değeri istatistiksel olarak anlamlı kabul edildi.

\section{BULGULAR}

Çalışmaya 35 obez ve 35 obez olmayan, toplam 70 migren tanısı alan hasta dahil edildi. Hastaların $38^{\prime} \mathrm{i}$ kız, 32'si erkek idi. Yaş ortalaması $14,04 \pm 2,4$ 'dü ve tüm hastaların pübertesi başlamıştı. Her iki grubun demografik ve antropometrik özellikleri, tablo 2'de ayrıntılı olarak verilmiştir. Tüm hastaların ortalama baş ağrısı süresi $32,08 \pm 18,67$ ay, migren tanısı ile izlenme süreleri ise $12,28 \pm 5,83$ aydı. Obez hastalarda aylık atak sıklığı 9,94 $\pm 8,37$ gün iken obez olmayan hastalarda $7,02 \pm 5,28$ idi. Atak süresi obez olmayanlarda $18,6 \pm 18,95$ saat iken, obezlerde $20,41 \pm 22,12$ saat idi. Hastalığın atak şiddeti (10 üzerinden) obez olmayanlarda 7,4 0,97 , obezlerde $7,91 \pm 1,01$ idi. PedMIDAS skorları da obez hastalarda $26,74 \pm 20,32$ iken obez olmayanlarda $23,11 \pm 18,39$ 'du. Her iki grubun migren ile ilgili özellikleri tablo 3 'te karşılaştırılmıştır.

Tablo 1. PEDMIDAS* Skorlamasına göre tedavi öncesi ve sonrası değerlendirme (üç aylık izlem süresinde)

\begin{tabular}{|l|}
\hline Okula devamsızlık gün sayısı \\
\hline Okul performansında \%50 azalma olan gün sayısı \\
\hline Ev ödevi yapmadı̆̆1 gün sayısı \\
\hline Ev işi performansında \%50 azalma olan gün sayısı \\
\hline Ailevi, sosyal ve boş zaman aktivitelerinde kaçırdığı gün sayıs1 \\
\hline Baş ağrısı olan gün sayısı \\
\hline Baş ağrısının şiddeti (10 üzerinden) \\
\hline *PedMIDAS, Pediatric Migraine Disability Assessment Score. \\
\hline
\end{tabular}


Tablo 2. Obez olan ve olmayan migren hastalarının demografik ve antropometrik özelliklerinin karşılaştırılması

\begin{tabular}{|c|c|c|c|}
\hline & Obez olanlar & Obez olmayanlar & $\mathbf{p}$ \\
\hline Cinsiyet (K/E) & $18 / 17$ & $20 / 15$ & $0.067^{*}$ \\
\hline Yaş (desimal yıl) & $13,48 \pm 2,67$ & $14,60 \pm 2,14$ & $0.382^{*}$ \\
\hline Boy (cm) & $161,1 \pm 9,6$ & $159 \pm 11,3$ & $0.403^{*}$ \\
\hline Boy Persentili & $59,6 \pm 26,1$ & $47,3 \pm 33$ & $0.090^{*}$ \\
\hline Boy SDS & $0,30 \pm 0,89$ & $0,02 \pm 1,15$ & $0.257^{*}$ \\
\hline Ağırlık (kg) & $81,6 \pm 16,3$ & $50,6 \pm 10$ & $<0.001$ \\
\hline Ağırlık Persentili & $97,5 \pm 3,6$ & $39,9 \pm 28,6$ & $<0.001$ \\
\hline Ăğırlık SDS & $2,74 \pm 1,19$ & $-0,41 \pm 1,02$ & $<0.001$ \\
\hline VKİ & $31 \pm 3,9$ & $19,7 \pm 2,1$ & $<0.001$ \\
\hline VKİ-P & $98,5 \pm 1,3$ & $40,8 \pm 23,3$ & $<0.001$ \\
\hline VKİ-SDS & $2,13 \pm 0,22$ & $-0,34 \pm 0,82$ & $<0.001$ \\
\hline \multicolumn{4}{|c|}{$\begin{array}{l}\text { Pearson ki-kare* ve Student t test ile değerlendirilmiştir. } p<0.05 \text { anlamlı olarak kabul edilmiştir. Gruplar arası cinsiyet, yaş, boy } \\
\text { ve boy ile ilgili hesaplamalar dağılımı Pearson ki-kare ile değerlendirilmiş ve fark bulunamamıştır. }(p<0.05)\end{array}$} \\
\hline
\end{tabular}

Tablo 3. Obez olan ve obez olmayan hastaların migren özelliklerinin karşılaştırılması

\begin{tabular}{|l|c|c|c|}
\hline & Obez olmayanlar & Obez olanlar & p \\
\hline $\begin{array}{l}\text { Baş ağrısı başlangıcından bu yana geçen } \\
\text { süre(ay) }\end{array}$ & $33,20 \pm 15,48$ & $30,97 \pm 21,58$ & $0.867^{* *}$ \\
\hline Migren tanısı süresi (ay) & $13,14 \pm 6,21$ & $11,42 \pm 5,32$ & 0.625 \\
\hline Migren sıklığı (gün/ay) & $7,02 \pm 5,28$ & $9,94 \pm 8,37$ & 0.592 \\
\hline Migren atak süresi (saat) & $18,60 \pm 18,95$ & $20,41 \pm 22,12$ & 0.940 \\
\hline Ağrı ciddiyeti (10 üzerinden) & $7,40 \pm 0,97$ & $7,91 \pm 1,01$ & 0.216 \\
\hline PedMIDAS* & $23,11 \pm 18,39$ & $26,74 \pm 20,32$ & 0.467 \\
\hline $\begin{array}{l}\text { Iki grup arasındaki ortalamaların karşılaştırılması için Mann-Whitney U testi** ve Student's t test kullanıldı. } p<0.05 \text { değeri } \\
\text { istatistiksel olarak anlamlı kabul edildi. }\end{array}$ \\
\hline *PedMIDAS, Pediatric Migraine Disability Assessment Score.
\end{tabular}

\section{TARTIŞMA}

Ülkemizde yapılan çalışmalarda çocukluk yaş grubunda obezite sıklığının yaklaşık \%7-\%14,6 arasında değişmekte olduğu gösterilmiştir (1619). Bu sıklıktaki artışın son 12 yılda 3 kat, son 20 yılda ise 11 kat olduğunun gösterilmesi obezite ve ilişkili olabilecek hastalıkların saptanmasını önemli kılmıştır $(17,19)$. Erişkinlerde obezite ve migren ilişkisini araştıran geniş çaplı araştırmalar mevcuttur (9,12). Obez çocuk ve adolesanlarda ise baş ağrısı sıklığının arttığına dair bazı çalışmalar mevcut olsa da buna karşıt olan çalışmalar da mevcuttur (20-22). Hancı ve arkadaşlarının yaptığı çalışmada 281 çocuk arasından BMI 25 ve üstü olanlarda primer baş ağrısının sıklığının arttığı görülmüştür. Özellikle de BMI değerleri 30 ve üstü olanlarda bu oranın en yüksek olduğu yine kız çocuklarında erkeklere göre daha sık rastlanıldığı gözlenmiştir (22). Pinhas-Hamiel ve ark.'nın yaptığı ve bu ilişkiyi ilk inceleyen çalışmada, 273 çocuk ve ergende 
migren prevelansı ve obesite ilişkisi değerlendirlmiştir. Migren sıklığı normal kilolu çocuklarda $\% 4,4$ ve fazla kilolularda ise $\% 7,3$ olarak bulunmuştur (20). 5847 çocuk hastada yapılan başka bir çalışmada, obez hastalarda migren sıklığı \%60 gibi çok yüksek bir oranda bulunmuş ve sadece yaşam tarzı değişiklikleri ile olumlu bir fayda sağlanabileceği belirtilmiştir (23). Ravid ve ark.'nın yaptığı çalışmada ise, migrenin toplum sıklığına göre fazla kilolularda 2,5 kat, obezlerde ise 3,5 kat daha fazla gözlendiği gösterilmiştir (24). Yapılan prevalans çalışmalarında migren sıklığının obez bireylerde daha sık olduğu birçok çalışmada gösterilmiş olmasına rağmen literatürde çocukluk yaş grubunda obez olanlar ile olmayanlar arasında migren özelliklerinin karşılaştırıldığı çok az sayıda çalışma mevcuttur. Bu çalışmada, randomize olarak obez ve obez olmayan $35^{\prime}$ er migren hastası ele alınıp migren özellikleri değerlendirildi ve iki grup arasında istatistiksel olarak anlamlı bir fark bulunamadı.

Çalışmamızda obez olan grubun, normal kilolu gruba göre PedMIDAS skorlarının daha yüksek olduğu ancak bu farkın anlamlı olmadığı görüldü. Obez olanlarda atak sıklığı, süresi ve şiddeti obez olmayanlara göre daha yüksek ortalamaya sahip olsa da yine bu fark anlamlı değildi. Ülkemizde yapılmış başka bir çalışmada, migren sıklığının obezlerde anlamlı bir şekilde artmış olduğu ve buna ek olarak bizim çalışmamızla benzer nitelikte, migren atak süresinin ve şiddetinin obez olan ve olmayan hastalarda farklı olmadığı gösterilmiştir (11). Aslında migren özelliklerinden migrenin sıklığının ve şiddetinin de bu skorlamanın bir bileşeni olduğu düşünülürse PedMIDAS skorunun iki grup arasında farklılık göstermesi beklenirdi. Ancak PedMIDAS skorlama sistemindeki günlük yaşamın etkilenmesine dair sorular da mevcuttur. Bizim hasta gruplarımızda PEDMIDAS skorlarının farklı olmaması iki sebebe bağlanabilir. Birincisi her ne kadar sıklık ve şiddet fazla olsa bile günlük yaşamı etkileyebilecek kadar bir fark yaratmamış olabilir. íkincisi ise obez hastaların egzersiz ve yaşam tarzı yönetimi gibi kilo verme tedavilerinin aynı zamanda migren için fayda gösterdiği ve çalışmamızda obez olan hastaların yaşam tarzı değişiklikleri, egzersiz ve kilo verdirici diet tedavileri ile izleniyor olması olabilir. Sonuç olarak çalışmamızda günlük aktivitenin obez migrenlerde normal kilolara göre daha fazla etkilenmediğini göstermektedir (25).

Gerek erişkin gerekse çocuk popülasyonu ile yapılan çalışmalarda kız hastalarda migren sıklığının ve migren tanısı olanlarda atak sıklığının daha fazla olduğu gösterilmiştir $(26,27)$. Bizim randomize gruplarımızda cinsiyet dağılımının benzer olaması nedeniyle, atak sıklığı ve PedMIDAS sonuçlarına bu yönde bir etki gözlenmemiştir. Bu alanda yapılan çalışmalarda cinsiyet dağılımının önemi bu sebeple önemlidir ve çoğu zaman gözden kaçmakta ve gruplar arası karşılaştırmaların yanlış sonuçlanmasına sebep olmaktadır.

Her ne kadar yapılan birçok çalışmada obez hastalarda migren sıklığının artmış olduğu gösterilse de, 2012 yılında, 925 çocuk hastada yapılmış bir çalışmada, migren sıklığının obezlerde normal popülasyona göre farklı olmadığı bulunmuştur (21). Literatürdeki birçok çalışmadan farklı olan bu sonuç, her iki kronik hastalığın çoklu etiyolojiye sahip olması ve şiddetlerinin çok yönlü etkilenim ile ilişkili olmasına bağlı olarak, değişik hasta gruplarında değişik sonuçların çıkabileceğini göstermektedir. Bunun için migren sıklığı çalışmalarından ziyade, bizim çalışmamamızda yaptığımız gibi hem migren sıklığı, şiddeti, süresi gibi kantitatif bileşenleri değerlendiren hem de migrenin okul devamsızlığına sebep olma, sosyal hayatı erteleme gibi kalitatif süreçlere de etkisini araştıran skorlama sistemlerini içeren, obezite ve migren ilişkisini araştıran çalışmaların yapılmasına intiyaç vardır.

Bizim çalışmamızdan farklı olarak erişkin kadınlarda yapılmış bazı çalışmalarda migren atak sıklığının obezite ile arttığı bulunmuştur $(28,29)$. 
Belki de olgu sayılarının arttırılması ve kızlarla erkeklerin ayrı gruplarda değerlendirilmesi halinde çocukluk çağındaki kızlarda da farklı sonuçlar elde edilebilir. Bu açıdan yeni çalışmalara ihtiyaç vardır. Zhou ve ark' nın (30) migren tanılı erişkin kadınlarda yaptığı çalışmada metabolik sendromu olan kadınlarda, olmayanlara göre ağrı kesici kullanımının daha fazla olduğu bulunmuş ve kullanılan ağrı kesicilerin metabolik sendromun oluşunu tetiklediği yorumu yapılmıştır. Son zamanlara ait çocukluk çağı grupları ile yapılan $\mathrm{Hancı}$ ve arkadaşlarının çalışması, migrenin obez hastalardaki kız erkek ayrımını ortaya koyması açısından önemlidir ve bu çalışmada kız hastalarda belirgin yüksek bir oran saptamıştır. Bizim çalışmamızda obez çocukların metabolik sendrom ya da insülin direnci varlığı açısından değerlendirilmemesi bir kısıtlılık olarak düşünülebilir, belki de bu açıdan gruplama yapılacak olursa migren özellikleri arasında farklııklar bulunabilirdi. Bu, gelecekte planlanacak yeni bir çalışma konusu olabilir. Ayrıca çocuklarda ağrı kesici kullanımının değerlendirilmesi için daha uzun izlem süreli çalışmaların planlanması gerekmektedir. Yine obez olan migren hastalarının kilo verdikten sonra migren özelliklerinin tekrar değerlendirildiği bir çalışma ile, obezitenin migren üzerine etkisininin daha iyi anlaşılabileceğini düşünüyoruz. Daha çok hasta sayısı ile yapılacak güncel çalışmalar, çocuklarda migren ve obezite ilişkisini aydınlatacaktır.

Bilgilendirilmiş Onam: Katılımcılardan yazııı onam alınmıştır. Sağlık Bilimleri Üniversitesi İzmir Tepecik Sağlık Uygulama Araştırma Merkezi Girişimsel Olmayan Etik Kurulu'ndan 2019/18-5 no ile 26/12/2019 tarihinde onam alınmıştır.

Çıkar Çatışması: Yazarlar çıkar çatışması beyan etmemişlerdir.

Finansal Destek: Yazarlar finansal destek beyan etmemişlerdir.

\section{KAYNAKLAR}

1. Hoxie Bigal ME, Lipton RB. Obesity is a risk factor for transformed migraine but not chronic tension-type headache. Neurology. 2006; 67:252-7.

2. Bigal ME, Lipton RB. Obesity and chronic daily headache. Curr Pain Headache Rep. 2008; 12:56-61.

3. Jansen-Olesen I, Mortensen A, Edvinsson L. Calcitonin gene-related peptide is released from capsaicinsensitive nerve fibres and induces vasodilatation of human cerebral arteries concomitant with activation of adenylyl cyclase. Cephalalgia. 1996; 16:310-6.

4. Holland PR, Akerman S, Goadsby PJ. Orexin 1 receptor activation attenuates neurogenic dural vasodilation in an animal model of trigeminovascular nociception. J Pharmacol Exp Ther. 2005; 315:1380-5.

5. Peterlin BL, Alexander G, Tabby D, Reichenberger E. Oligomerization state-dependent elevations of adiponectin in chronic daily headache. Neurology. 2008; 70:1905-11.

6. Guldiken B, Guldiken S, Demir M, Turgut N, Tugrul A. Low leptin levels in migraine: a case control study. Headache. 2008; 48:1103-7.

7. Baranowska B, Wolinska-Witort E, Martynska L, Chmielowska M, Baranowska-Bik A. Plasma orexin A, orexin $B$, leptin, neuropeptide $Y$ (NPY) and insulin in obese women. Neuro Endocrinol Lett. 2005; 26:293-6.

8. Ahima RS, Flier JS. Adipose tissue as an endocrine organ. Trends Endocrinol Metab. 2000; 11:327-32.

9. Vo M, Ainalem A, Qiu C, Peterlin BL, Aurora SK, Williams MA. Body mass index and adult weight gain among reproductive age women with migraine. Headache. 2011; 51:559-69.

10. Ray S, Singh SB, Halford JCG, Harrold JA, Kumar R. A Pilot Study of Obesogenic Eating Behaviors in Children with Migraine. J Child Neurol. 2016; 31:895-8.

11. Kinik ST, Alehan F, Erol I, Kanra AR. Obesity and paediatric migraine. Cephalalgia. 2010; 30:105-9.

12. Bigal ME, Liberman JN, Lipton RB. Obesity and migraine: a population study. Neurology. 2006; 66:545-50.

13. Hershey AD, Powers SW, Nelson TD, Kabbouche MA, Winner $\mathrm{P}$, Yonker $\mathrm{M}$, et al. Obesity in the pediatric headache population: a multicenter study. Headache. 2009; 49:170-7.

14. Hershey AD, Powers SW, Vockell ALB, LeCates SL, Segers A, Kabbouche MA. Development of a patientbased grading scale for PedMIDAS. Cephalalgia. 2004; 24:844-9.

15. Neyzi O, Bundak R, Gokcay G, Gunoz H, Furman A, Darendeliler $F$, et al. Reference Values for Weight, Height, Head Circumference, and Body Mass Index in Turkish Children. J Clin Res Pediatr Endocrinol. 2015; 7:280-93.

16. Yardim MS, Ozcebe LH, Araz OM, Uner S, Li S, Unlu HK, 
et al. Prevalence of childhood obesity and related parental factors across socioeconomic strata in Ankara, Turkey. East Mediterr Health J. 2019; 25:374-84.

17. Celmeli G, Curek Y, Arslan Gulten Z, Yardimsever M, Koyun M, Akcurin S, et al. Remarkable Increase in the Prevalence of Overweight and Obesity Among School Age Children in Antalya, Turkey, Between 2003 and 2015. J Clin Res Pediatr Endocrinol. 2019; 11:76-81.

18. Santas F, Santas G. Prevalence of pre-school children for overweight/obesity in Turkey. World J Pediatr. 2018; 14:77-83.

19. Alper Z, Ercan I, Uncu Y. A Meta-Analysis and an Evaluation of Trends in Obesity Prevalence among Children and Adolescents in Turkey: 1990 through 2015. J Clin Res Pediatr Endocrinol. 2018; 10:59-67.

20. Pinhas-Hamiel O, Frumin K, Gabis L, Mazor-Aronovich K, Modan-Moses D, Reichman B, et al. Headaches in overweight children and adolescents referred to a tertiary-care center in Israel. Obesity (Silver Spring). 2008; 16:659-63.

21. Pakalnis A, Kring D. Chronic daily headache, medication overuse, and obesity in children and adolescents. J Child Neurol. 2012; 27:577-80.

22. Hancı F, Kabakuş N, Türay S, Bala KA, Dilek M. The role of obesity and vitamin $D$ deficiency in primary headaches in childhood. Acta Neurol Belg. 2020; 120:1123-31.

23. Robberstad L, Dyb G, Hagen K, Stovner L, Holmen TL, Zwart J-A. An unfavorable lifestyle and recurrent headaches among adolescents: the HUNT study. Neurology. 2010; 75:712-7.

24. Ravid S, Shahar E, Schiff A, Gordon S. Obesity in children with headaches: association with headache type, frequency, and disability. Headache. 2013; 53:954-61.

25. Verrotti A, Agostinelli S, D’Egidio C, Di Fonzo A, Carotenuto $M$, Parisi $P$, et al. Impact of a weight loss program on migraine in obese adolescents. Eur J Neurol. 2013; 20:394-7.

26. Farello G, Ferrara P, Antenucci A, Basti C, Verrotti A. The link between obesity and migraine in childhood: $a$ systematic review. Ital J Pediatr. 2017; 43:27.

27. Pavlovic JM, Vieira JR, Lipton RB, Bond DS. Association Between Obesity and Migraine in Women. Curr Pain Headache Rep. 2017; 21:41.

28. Rossoni de Oliveira V, Camboim Rockett F, Castro K, da Silveira Perla A, Chaves ML, Schweigert Perry ID. Body mass index, abdominal obesity, body fat and migraine features in women. Nutr Hosp. 2013; 28:1115-20.

29. Fava A, Pirritano D, Consoli D, Plastino $M$, Casalinuovo F, Cristofaro S, Colica C, Ermio C, De Bartolo M, Opipari C, Lanzo R, Consoli A, Bosco D. Chronic migraine in women is associated with insulin resistance: a crosssectional study. Eur J Neurol. 2014; 21:267-72.

30. He Z, Dong L, Zhang Y, Kong Q, Tan G, Zhou J. Metabolic syndrome in female migraine patients is associated with medication overuse headache: a clinic-based study in China. Eur J Neurol. 2015; 22:1228-34. 